\title{
Pengembangan perangkat pembelajaran matematika berciri scientific pada materi barisan aritmatika dan geometri untuk siswa SMP kelas IX
}

\author{
Mohammad Agung, Ipung Yuwono* \\ Universitas Negeri Malang, Jl. Semarang No. 5 Malang, Jawa Timur, Indonesia \\ *Penulis korespondensi, Surel: ipungmat@um.ac.id
}

Paper received: 01-12-2021; revised: 15-12-2021; accepted: 31-12-2021

\begin{abstract}
Abstrak
Matematika merupakan salah satu ilmu pengetahuan yang memegang peran penting dalam menyelesaikan berbagai masalah dalam kehidupan sehari-hari. Tujuan dari penelitian ini adalah untuk menghasilkan perangkat pembelajaran berupa RPP dan LKS materi barisan aritmatika dan barisan geometri untuk siswa SMP kelas IX yang valid, praktis, dan efektif. Pengembangan perangkat pembelajaran ini memodifikasi model pengembangan Plomp yang terdiri atas: (1) tahap investigasi awal, (2) tahap desain, (3) tahap realisasi, dan (4) tahap tes, evaluasi, dan revisi. Berdasarkan analisis pengembangan diperoleh hasil bahwa perangkat pembelajaran yang dikembangkan dinyatakan valid, praktis, dan efektif. Walaupun demikian, sebagai penyempurnaan, pengembang tetap melakukan revisi berdasarkan saran dan komentar yang diberikan oleh validator dan siswa.
\end{abstract}

Kata kunci: perangkat pembelajaran; pendekatan scientific; barisan aritmatika dan barisan geometri

\section{Pendahuluan}

Matematika merupakan salah satu ilmu pengetahuan yang memegang peran penting dalam menyelesaikan berbagai masalah dalam kehidupan sehari-hari. Matematika melatih seseorang untuk berpikir logis dan kritis dalam menghadapai suatu masalah. Matematika juga melatih seseorang untuk tidak terpaku pada satu jalan dalam menyelesaikan masalah. Yasoda (2009) mengatakan "Matematika selalu digunakan sebagai alat untuk mempertajam intelektual. Untuk inilah, seseorang perlu untuk berpikir sistematis dan logis". Kemampuan matematika yang mumpuni juga menjadi syarat bagi seorang anak jika ingin melanjutkan ke jenjang pendidikan yang lebih tinggi yang mereka inginkan.

Seiring dengan perkembangan pendidikan di dunia, kurikulum di Indonesia telah mengalami berbagai perubahan yang bertujuan untuk memperbaiki kualitas pendidikan Indonesia. Perubahan kurikulum ini tentu saja berpengaruh juga pada sebaran serta tingkat kedalaman materi matematika yang diajarkan di sekolah. Kurikulum terbaru yang digunakan di Indonesia adalah kurikulum 2013 yang merupakan perbaikan dari kurikulum 2004 dan 2006. Pada kurikulum 2013 ini, pendekatan yang ditekankan adalah pendekatan scientific, seperti yang dipaparkan pada peraturan menteri pendidikan dan kebudayaan republik indonesia nomor 81A tahun 2013 tentang implementasi kurikulum 2013 Kurikulum 2013 menekankan pada dimensi pedagogik modern dalam pembelajaran, yaitu menggunakan pendekatan ilmiah. Pendekatan ilmiah (Scientific Approach) dalam pembelajaran semua mata pelajaran meliputi menggali informasi melalui pengamatan, bertanya, percobaan, kemudian mengelola data atau informasi, menyajikan data atau informasi, dilanjutkan dengan menganalisis, menalar, kemudian menyimpulkan, dan mencipta. 
Seiring dengan perubahan kurikulum dan pendekatan yang ditekankan, tentu saja harus disertai dengan perubahan pada perangkat ajar yang digunakan. Lembar kerja siswa, rencana pelaksanaan pembelajaran, serta media yang digunakan dalam proses pembelajaran haruslah menunjang pendekatan saintifik. Sayangnya, guru seringkali mengembangkan perangkat pembelajaran sebatas hanya sebagai persyaratan administratif (Lestari, 2013).

Masalah pemahaman konsep yang dialami siswa juga tidak lepas dari penggunaan perangkat pembelajaran yang digunakan dalam kegiatan pembelajaran. Saat ini, masih banyak ditemukan Rencana Pelaksanaan Pembelajaran (RPP) yang kegiatan pembelajarannya masih berpusat pada guru (teacher centered). Rencana Pelaksanaan Pembelajaran (RPP) kurang kurang memeberikan kesempatan kepada siswa untuk membangun konsep sendiri serta kurang mengaitkan materi pembelajaran dengan kehidupan sehari-hari. Untuk menghasilkan proses pembelajaran yang baik dan sesuai dengan tujuan pembelajaran tentunya diperlukan perencanaan yang matang. Menurut Setyosari (2001) untuk menghasilkan perencanaan pembelajaran yang baik maka dibutuhkan sebuah desain pembelajaran yang disebut rancangan pembelajaran yang baik pula.

Berdasarkan hasil wawancara dengan salah satu guru di MTs N Malang 3, pada tanggal 29 Agustus 2014, menunjukkan bahwa, dalam pembelajaran di kelas, guru cenderung menjadi pusatnya, guru memaparkan materi melalui power point dan siswa memperhatikan, dan kadang-kadang menganggapi pertanyaan yang diberikan oleh guru. Lembar kerja yang digunakan pun hanya berisi materi dan latihan soal. Berdasarkan hasil wawancara ini, pengembang menduga bahwa, lembar kerja yang digunakan tersebut belum bisa memacu siswa untuk membangun pemahaman mereka sendiri terhadap materi yang diajarkan.

Barisan aritmatika dan barisan geometri merupakan materi yang cukup penting, karena di jenjang yang lebih tinggi, materi ini akan digunakan pada materi-materi lain. Contohnya, pada materi integral, pada materi barisan tak hingga, dan materi lainnya di tingkat SMA. Selain itu, barisan aritmatika dan barisan geometri merupakan salah satu materi yang sulit. Hal ini terlihat dari hasil wawancara dengan beberapa siswa kelas IX di MTs N Malang 3. Menurut mereka, pada materi ini mereka sering kali kesulitan ketika menyelesaikan soal cerita. Mereka seringkali tidak bisa membedakan harus menggunakan konsep barisan ataukah deret dalam menyelesaikan persoalan tersebut. Hal ini dikuatkan oleh hasil penelitian yang dilakukan oleh Nurdin (2005) yang menyebutkan bahwa banyak siswa dapat menentukan suku ke-n suatu barisan aritmatika dan barisan geometri namun tidak dapat mengaplikasikan pengetahuan mereka mengenai konsep barisan untuk menyelesaikan soal-soal aplikasi barisan aritmatika dan barisan geometri.

Pada pelakasanaan kurikulum 2013 ternyata menimbulkan masalah yang tidak sederhana. Dengan memperhatikan masalah-masalah tersebut, mendikbud menyerahkan kepada sekolah-sekolah untuk melanjutkan atau menghentikan penerapan kurikulum 2013 di sekolah masing-masing. Namun mendikbud menyarankan untuk menghentikan pelaksanaan kurikulum 2013 di sekolah-sekolah yang baru menerapkan selama satu semester dan kembali pada kurikulum 2006 dan tetap melaksanakan kurikulum 2013 di sekolah yang telah melaksanakannya selama tiga semester dan menjadikan sekolah-sekolah tersebut sebagai percontohan penerapan kurikulum 2013. Setelah kurikulum 2013 telah 
diperbaiki dan dimatangkan, baru dimulai proses penyebaran penerapan kurikulum 2013 ke sekolah-sekolah lain. (Mendikbud, 2014:2)

Berdasarkan uraian di atas, diperlukan pengembangan perangkat pembelajaran berupa RPP dan LKS dengan pendekatan scientific untuk materi barisan aritmatika dan barisan geometri. RPP adalah bentuk perencanaan yang menggambarkan kegiatan-kegiatan yang akan dilakukan oleh guru dan siswa dalam suatu kegiatan pembelajaran untuk mengarahkan siswa mencapai Kompetensi Dasar (KD). Sedangkan LKS merupakan bahan ajar berisi tugas yang harus diselesaikan oleh siswa dengan mengikuti langkah-langkah atau petunjuk yang ada agar siswa dapat belajar secara terarah untuk mencapai KD. Dengan demikian, perangkat pembelajaran berciri scientific adalah RPP dan LKS dimana aktivitas siswa disusun berdasarkan lima karakteristik scientific yaitu mengamati, menanya, mengumpulkan informasi, mengolah informasi, dan mengomunikasikan.

\section{Metode}

Penelitian ini merupakan penelitian pengembangan, yaitu pengembangan perangkat pembelajaran materi barisan aritmatika dan barisan geometri berciri scientific yang mengacu pada model yang dikemukakan oleh Plomp (Hobri, 2010). Model pengembangan yang dikemukakan oleh Plomp terdiri atas 5 tahap, yaitu 1) tahap investigasi awal, 2) tahap desain, 3) tahap realisasi, 4) tahap evaluasi, tes, dan revisi, dan 5) tahap implementasi. Namun, penelitian ini hanya dilakukan sampai pada tahap tes, evaluasi, dan revisi dikarenakan ketersediaan biaya dan waktu pelaksanaan.

Pada penelitian ini, dilakukan 3 uji untuk mengetahui kualitas produk yang dikembangkan, yaitu uji kevalidan, uji kepraktisan, dan uji keefektifan. Uji kevalidan dilakukan untuk melihat apakah produk yang telah dikembangkan peneliti telah sesuai dengan teori pengembangan perangkat pembelajaran dan lima karakteristik pendekatan scientific. Uji kepraktisan dilakukan untuk mengetahui keterterapan perangkat pembelajaran yang dihasilkan dalam proses pembelajaran, apakah mudah dan menyenangkan untuk digunakan atau tidak. Sedangkan uji keefektifan dilakukan unuk mengetahui sejauh mana produk yang dihasilkan dapat membantu siswa mempelajari materi yang diajarkan.

Uji kevalidan menggunakan angket validasi RPP dan LKS yang diisi oleh 1 orang dosen matematika dan 1 orang guru matematika SMP yang telah berpengalaman di bidangnya. Uji kepraktisan dilakukan menggunakan angket uji kepraktisan RPP yang diisi oleh 1 orang guru dan 2 orang observer, serta angket respon siswa yang diisi oleh 9 orang siswa kelas IX sebagai subjek uji coba. Uji keefektifan dilakukan dengan melihat nilai hasil pengerjaan latihan pada LKS dan nilai Kuis.

Teknik analisis data hasil uji kevalidan dan kepraktisan yang dilakukan sesuai teknik analisis dalam Hobri (2010), yaitu: 1) melakukan rekapitulasi data penilaian produk ke dalam tabel yang meliputi aspek, indikator, dan nilai untuk masing-masing validator, 2) menentukan rata-rata nilai hasil penilaian dari semua validator untuk setiap indikator, 3) menentukan rerata nilai untuk setiap aspek, dan 4) menentukan persentase kevalidan atau kepraktisan $(P)$, yaitu persentase rerata nilai untuk semua aspek dari nilai tertinggi. Selanjutnya, hasil yang diperoleh akan dibandingkan dengan kriteria kevalidan atau kepraktisan perangkat pembelajaran seperti pada Tabel 1 . 
Tabel 1. Kriteria Kevalidan atau Kepraktisan Perangkat Pembelajaran

\begin{tabular}{cll}
\hline Persentase & Kategori & Keterangan \\
\hline $85 \leq P \leq 100$ & Sangat valid/sangat praktis & Tidak perlu revisi \\
$70 \leq P<85$ & Valid/praktis & Tidak perlu revisi \\
$55 \leq P<70$ & Cukup valid/cukup praktis & Revisi sebagian \\
$40 \leq P<55$ & Kurang valid/kurang & Revisi sebagian \\
& praktis & \\
$0 \leq P \leq 40$ & Tidak valid/tidak praktis & Revisi total \\
\hline
\end{tabular}

Sedangkan, teknik analisis data hasil uji keefektifan dilakukan dengan menentukan nilai akhir KD 6.2 masing-masing siswa. Perangkat pembelajaran dikatakan memenuhi kriteria aefektif apabila $100 \%$ siswa subjek uji coba mendapatkan nilai lebih dari atau sama dengan 80.

\section{Hasil dan Pembahasan}

Hasil dari pengembangan Lembar Kegiatan Siswa (LKS) yang memuat halaman identitas (memuat judul LKS dan satuan pendidikan), halaman identitas (memuat standar kompetensi, kompetensi dasar, indikator, dan tujuan pembelajaran), LKS utama (memuat LKS 1 dan LKS 2 dengan pendekatan saintifik), ayo berlatih (memuat dua soal untuk memantapkan pemahaman materi yang dibahas dalam kompetensi). Dalam LKS utama siswa akan melakukan lima kegiatan, yaitu: mengamati, menanya, mengumpulkan informasi, mengasosiasi, dan mengkomunikasikan.

Berikut disajikan hasil analisis uji kevalidan oleh validator

Tabel 2. Analisis Hasil Uji Kevalidan RPP

\begin{tabular}{lllll}
\hline No. & Aspek yang dinilai & $\begin{array}{l}\text { Persentase } \\
\text { kevalidan }\end{array}$ & $\begin{array}{l}\text { Kriteria } \\
\text { kevalidan }\end{array}$ & Keterangan \\
\hline 1. & Kelayakan Isi & $90 \%$ & Sangat Valid & Tidak perlu revisi \\
2. & Pendekatan saintifik & $82 \%$ & Valid & Tidak perlu revisi \\
3. & $\begin{array}{l}\text { Kebahasaan dan } \\
\text { Tampilan }\end{array}$ & $78 \%$ & Valid & Tidak perlu revisi \\
\hline
\end{tabular}

Secara keseluruhan aspek terhadap RPP yang telah dikembangkan, diperoleh persentase skor kevalidan sebesar 84\%dan berada pada kriteria kevalidan valid. Dengan demikian, dapat disimpulkan bahwa RPP yang dikembangkan valid dan tidak perlu revisi. Namun, peneliti tetap melakukan revisi berdasarkan saran dan masukan dari validator untuk menyempurnakan RPP yang dikembangkan.

Tabel 2. Analisis Hasil Uji Kevalidan LKS

\begin{tabular}{cllll}
\hline No. & Aspek yang dinilai & $\begin{array}{l}\text { Persentase } \\
\text { kevalidan }\end{array}$ & $\begin{array}{l}\text { Kriteria } \\
\text { kevalidan }\end{array}$ & Keterangan \\
\hline 1. & Kelayakan Isi & $88 \%$ & Sangat Valid & Tidak perlu revisi \\
2. & Pendekatan saintifik & $79 \%$ & Valid & Tidak perlu revisi \\
3. & Kebahasaan & $75 \%$ & Valid & Tidak perlu revisi \\
\hline
\end{tabular}


Pada Tabel 3 disajikan hasil analisis data dari uji kevalidan LKS yang dikembangkan. Secara keseluruhan, LKS yang telah dikembangkan memperoleh persentase skor kevalidan 79\% yang berada pada kriteria kevalidan valid. Berdasarkan hasil tersebut dapat disimpulkan bahwa LKS yang telah dikembangkan valid dan tidak perlu dilakukan revisi. Namun, peneliti tetap melakukan revisi berdasarkan saran dan masukan validator untuk memperbaiki penggunaan kalimat pada masalah kontekstual yang ada dalam LKS.

Selain uji kevalidan, produk yang dikembangkan berupa RPP dan LKS diuji kepraktisannya. Analisis data hasil uji kepraktisan RPP disajikan pada Tabel 4 sebagai berikut.

Tabel 4 Analisis Data Hasil Uji Kepraktisan RPP oleh Praktisi dan Observer

\begin{tabular}{|c|c|c|c|c|}
\hline No. & Aspek yang Dinilai & $\begin{array}{l}\text { Persentase } \\
\text { Kepraktisan }\end{array}$ & $\begin{array}{l}\text { Kriteria } \\
\text { Kepraktisan }\end{array}$ & Keterangan \\
\hline 1. & $\begin{array}{l}\text { Kesesuaian waktu yang disediakan } \\
\text { dengan proses pembelajaran secara } \\
\text { keseluruhan. }\end{array}$ & $75 \%$ & Praktis & $\begin{array}{l}\text { Tidak Perlu } \\
\text { Revisi }\end{array}$ \\
\hline 2. & $\begin{array}{l}\text { Tingkat ketercapaian tujuan } \\
\text { pembelajaran setelah proses } \\
\text { pembelajaran selesai. }\end{array}$ & $75 \%$ & Praktis & $\begin{array}{l}\text { Tidak Perlu } \\
\text { Revisi }\end{array}$ \\
\hline 3. & $\begin{array}{l}\text { Keefektifan pemanfaatan sumber belajar } \\
\text { dan media yang tercantum dalam RPP } \\
\text { oleh siswa dalam proses pembelajaran. }\end{array}$ & $83 \%$ & Praktis & $\begin{array}{l}\text { Tidak Perlu } \\
\text { Revisi }\end{array}$ \\
\hline 4. & $\begin{array}{l}\text { Kesesuaian langkah pembelajaran yang } \\
\text { dicantumkan pada RPP dan } \\
\text { implementasinya dalam kelas. }\end{array}$ & $75 \%$ & Praktis & $\begin{array}{l}\text { Tidak Perlu } \\
\text { Revisi }\end{array}$ \\
\hline 5. & $\begin{array}{l}\text { Kemampuan RPP menjadikan siswa aktif } \\
\text { dan kreatif dalam proses pembelajaran. }\end{array}$ & $100 \%$ & $\begin{array}{l}\text { Sangat } \\
\text { Praktis }\end{array}$ & $\begin{array}{l}\text { Tidak Perlu } \\
\text { Revisi }\end{array}$ \\
\hline 6. & $\begin{array}{l}\text { Kemampuan RPP mendorong siswa } \\
\text { mencari tahu dari berbagai sumber } \\
\text { belajar, dengan melakukan observasi, } \\
\text { bukan diberi tahu (kegiatan mengamati). }\end{array}$ & $83 \%$ & Praktis & $\begin{array}{l}\text { Tidak Perlu } \\
\text { Revisi }\end{array}$ \\
\hline 7. & $\begin{array}{l}\text { Kemampuan RPP mendorong siswa } \\
\text { merumuskan masalah dan bukan hanya } \\
\text { menyelesaikan masalah (kegiatan } \\
\text { menanya). }\end{array}$ & $83 \%$ & Praktis & $\begin{array}{l}\text { Tidak Perlu } \\
\text { Revisi }\end{array}$ \\
\hline 8. & $\begin{array}{l}\text { Kemampuan RPP mengarahkan siswa } \\
\text { untuk mengolah informasi dari hasil } \\
\text { pengamatan maupun mengumpulkan } \\
\text { informasi (kegiatan mengumpulkan dan } \\
\text { mengolah informasi) }\end{array}$ & $83 \%$ & Praktis & $\begin{array}{l}\text { Tidak Perlu } \\
\text { Revisi }\end{array}$ \\
\hline 9. & $\begin{array}{l}\text { Kemampuan RPP untuk mendorong } \\
\text { siswa menyampaikan hasil pengamatan } \\
\text { dan kesimpulan yang telah dibuat. }\end{array}$ & $92 \%$ & $\begin{array}{l}\text { Sangat } \\
\text { Praktis }\end{array}$ & $\begin{array}{l}\text { Tidak Perlu } \\
\text { Revisi }\end{array}$ \\
\hline 10. & $\begin{array}{l}\text { Instrumen penilaian mudah digunakan } \\
\text { dalam proses pembelajaran. }\end{array}$ & $92 \%$ & $\begin{array}{l}\text { Sangat } \\
\text { Praktis }\end{array}$ & $\begin{array}{l}\text { Tidak Perlu } \\
\text { Revisi }\end{array}$ \\
\hline 11. & $\begin{array}{l}\text { Kemampuan RPP menciptakan rasa } \\
\text { senang peserta didik dalam proses } \\
\text { pembelajaran }\end{array}$ & $100 \%$ & $\begin{array}{l}\text { Sangat } \\
\text { Praktis }\end{array}$ & $\begin{array}{l}\text { Tidak Perlu } \\
\text { Revisi }\end{array}$ \\
\hline
\end{tabular}

Secara keseluruhan, diperoleh persentase skor kepraktisan RPP yang dikembangkan adalah $86 \%$. Persentase skor ini menunjukkan bahwa RPP yang dikembangkan berada dalam 
kriteria kepraktisan praktis. Dengan demikian, revisi terhadap RPP yang dikembangkan tidak perlu dilakukan. Namun untuk kesempurnaan RPP yang dihasilkan, dilakukan revisi berdasarkan saran dan masukan dari praktisi dan observer yaitu menyesuaikan alokasi waktu pada RPP dengan waktu yang dibutuhkan pada saat uji coba RPP.

Tabel 5 Analisis Data Hasil Uji Kepraktisan LKS oleh Siswa Subjek Uji Coba

\begin{tabular}{|c|c|c|c|c|}
\hline No. & Aspek yang Dinilai & $\begin{array}{l}\text { Persentase } \\
\text { Kepraktisan }\end{array}$ & $\begin{array}{l}\text { Kriteria } \\
\text { Kepraktisan }\end{array}$ & Keterangan \\
\hline 1. & $\begin{array}{l}\text { Saya mudah memahami informasi, } \\
\text { pertunjuk kerja, dan pertanyaan pada } \\
\text { LKS yang digunakan dalam } \\
\text { pembelajaran. }\end{array}$ & $75 \%$ & Praktis & $\begin{array}{l}\text { Tidak Perlu } \\
\text { Revisi }\end{array}$ \\
\hline 2. & $\begin{array}{l}\text { LKS yang digunakan dalam } \\
\text { pembelajaran memuat kegiatan belajar } \\
\text { yang menarik. }\end{array}$ & $94 \%$ & $\begin{array}{l}\text { Sangat } \\
\text { Praktis }\end{array}$ & $\begin{array}{l}\text { Tidak Perlu } \\
\text { Revisi }\end{array}$ \\
\hline 3. & $\begin{array}{l}\text { Kegiatan belajar pada LKS yang } \\
\text { digunakan dalam pembelajaran } \\
\text { membuat saya terlibat aktif dalam } \\
\text { pembelajaran. }\end{array}$ & $89 \%$ & $\begin{array}{l}\text { Sangat } \\
\text { Praktis }\end{array}$ & $\begin{array}{l}\text { Tidak Perlu } \\
\text { Revisi }\end{array}$ \\
\hline 4. & $\begin{array}{l}\text { Kegiatan belajar pada LKS yang } \\
\text { digunakan dalam pembelajaran } \\
\text { memberi saya kesempatan untuk } \\
\text { menyampaikan ide dengan bahasa } \\
\text { sendiri. }\end{array}$ & $78 \%$ & Praktis & $\begin{array}{l}\text { Tidak Perlu } \\
\text { Revisi }\end{array}$ \\
\hline 5. & $\begin{array}{l}\text { Kegiatan belajar pada LKS yang } \\
\text { digunakan dalam pembelajaran } \\
\text { memberikan kesempatan pada saya } \\
\text { untuk menemukan konsep dan } \\
\text { menyelesaikan masalah. }\end{array}$ & $86 \%$ & $\begin{array}{l}\text { Sangat } \\
\text { Praktis }\end{array}$ & $\begin{array}{l}\text { Tidak Perlu } \\
\text { Revisi }\end{array}$ \\
\hline 6. & $\begin{array}{l}\text { Kegiatan belajar pada LKS yang } \\
\text { digunakan dalam pembelajaran } \\
\text { mendorong saya untuk } \\
\text { mengembangkan model untuk } \\
\text { menyelesaikan masalah. }\end{array}$ & $72 \%$ & Praktis & $\begin{array}{l}\text { Tidak Perlu } \\
\text { Revisi }\end{array}$ \\
\hline 7. & $\begin{array}{l}\text { Kegiatan belajar pada LKS yang } \\
\text { digunakan dalam pembelajaran } \\
\text { mendorong saya untuk berinteraksi } \\
\text { dan bekerjasama dengan teman atau } \\
\text { lingkungan. }\end{array}$ & $97 \%$ & $\begin{array}{l}\text { Sangat } \\
\text { Praktis }\end{array}$ & $\begin{array}{l}\text { Tidak Perlu } \\
\text { Revisi }\end{array}$ \\
\hline 8. & $\begin{array}{l}\text { Kegiatan belajar pada LKS yang } \\
\text { digunakan dalam pembelajaran } \\
\text { menuntut saya dapat menggunakan } \\
\text { pengetahuan yang telah saya miliki } \\
\text { sebelumnya untuk menemukan } \\
\text { konsep dan menyelesaikan masalah. }\end{array}$ & $86 \%$ & $\begin{array}{l}\text { Sangat } \\
\text { Praktis }\end{array}$ & $\begin{array}{l}\text { Tidak Perlu } \\
\text { Revisi }\end{array}$ \\
\hline 9. & $\begin{array}{l}\text { LKS yang digunakan dalam } \\
\text { pembelajaran memiliki tampilan yang } \\
\text { menarik. }\end{array}$ & $94 \%$ & $\begin{array}{l}\text { Sangat } \\
\text { Praktis }\end{array}$ & $\begin{array}{l}\text { Tidak Perlu } \\
\text { Revisi }\end{array}$ \\
\hline 10. & $\begin{array}{l}\text { LKS yang digunakan dalam } \\
\text { pembelajaran menggunakan tata } \\
\text { bahasa yang baik dan benar. }\end{array}$ & $81 \%$ & Praktis & $\begin{array}{l}\text { Tidak Perlu } \\
\text { Revisi }\end{array}$ \\
\hline
\end{tabular}


dalam kriteria kepraktisan praktis sehingga tidak perlu direvisi. Namun demikian, peneliti tetap melakukan revisi terhadap bagian-bagian yang memiliki kekurangan berdasarkan saran dari subjek uji coba, khususnya kalimat-kalimat perintah pada LKS sehingga maksud kalimat mudah diterima oleh siswa.

Uji keefektifan perangkat pembelajaran dilihat dari hasil analisis nilai akhir KD 6.2 yang diperoleh siswa subjek uji coba selama pembelajaran. Pada Tabel 6 disajikan data hasil perolehan nilai siswa subjek uji coba.

Tabel 6 Data Perolehan Nilai Siswa Subjek Uji Coba

\begin{tabular}{|c|c|c|c|c|c|c|c|}
\hline \multirow[b]{2}{*}{ Kelompok } & \multirow{2}{*}{$\begin{array}{l}\text { Nama } \\
\text { Siswa }\end{array}$} & \multicolumn{4}{|c|}{ Nilai } & \multirow[b]{2}{*}{$N_{i}$} & \multirow[t]{2}{*}{ Kriteria } \\
\hline & & $\begin{array}{l}\text { TK } \\
1 \\
\end{array}$ & $\begin{array}{l}\text { TI } \\
1 \\
\end{array}$ & $\begin{array}{l}\text { TK } \\
2 \\
\end{array}$ & TI 2 & & \\
\hline \multirow{3}{*}{1} & ARP & & 100 & & 93,3 & 97,65 & Tuntas \\
\hline & IAN & 100 & 75 & 100 & 86,67 & 86,58 & Tuntas \\
\hline & $\mathrm{ADH}$ & & 95 & & 80 & 91,25 & Tuntas \\
\hline \multirow{3}{*}{2} & LS & & 85 & & 80 & 87,15 & Tuntas \\
\hline & LDS & 96 & 90 & 100 & 93,3 & 93,55 & Tuntas \\
\hline & MYA & & 85 & & 93,3 & 91,81 & Tuntas \\
\hline \multirow{3}{*}{3} & ASN & & 90 & & 93,3 & 90,55 & Tuntas \\
\hline & NMZ & 92 & 95 & 84 & 86,67 & 89,98 & Tuntas \\
\hline & IA & & 80 & & 80 & 82,4 & Tuntas \\
\hline Jumlah & & & & & & 810,94 & \multirow{2}{*}{ Tuntas } \\
\hline Rata-rata & & & & & & 90,1 & \\
\hline
\end{tabular}

Keterangan

TK 1 : Nilai hasil pengerjaan latihan LKS 1

TI 1 : Nilai Kuis 1

TK 2 : Nilai hasil pengerjaan latihan LKS 2

TI 2 : Nilai Kuis 2

$N_{i} \quad$ : Nilai akhir subjek uji coba ke-i diperoleh dengan rumus

$$
N_{i}=\frac{15 T K 1+35 T I 1+15 T K 2+35 T I 2}{100}
$$

Dari pemaparan hasil uji keefektifan perangkat pembelajaran diatas, dapat disimpulkan bahwa perangkat pembelajaran memenuhi kriteria efektif. Hal ini ditunjukkan dengan persentase subjek uji coba yang mendapatkan nilai akhir KD 6.2 lebih dari atau sama dengan 80 yaitu 100\%.

\section{Simpulan}

Berdasarkan hasil penelitian yang telah dilakukan oleh peneliti, dapat disimpulkan bahwa RPP yang dikembangkan telah memenuhi komponen RPP secara umum yang disebutkan Lestari (2013), yaitu identitas mata pelajaran, standar kompetensi, kompetensi dasar, indikator ketercapaian kompetensi, tujuan pembelajaran, materi ajar, alokasi waktu, metode pembelajaran, langkah-langkah pembelajaran, penilaian, dan sumber belajar. Sedangkan LKS yang dikembangkan sesuai dengan struktur umum LKS yang disebutkan dalam Pedoman Pengembangan Bahan Ajar (Depdiknas, 2008) yaitu judul LKS, petunjuk belajar, informasi pendukung, dan tugas-tugas. Selain itu, langkah-langkah pembelajaran RPP dan aktivitas siswa pada LKS untuk pembelajaran materi barisan aritmatika dan barisan 
geometri sudah sesuai dengan lima karakteristik pendekatan scientific yang meliputi mengamati, menanya, mengumpulkan informasi, mengolah informasi, dan mengomunikasikan.

Pengembangan perangkat pembelajaran ini menggunakan uji kevalidan, uji kepraktisan, dan uji keefektifan. Berdasarkan analisis data hasil uji kevalidan oleh dosen dan guru, RPP dinyatakan valid dengan persentase skor kevalidan $84 \%$ sedangkan LKS dinyatakan valid dengan skor kevalidan 79\%. Hal ini menunjukkan bahwa RPP dan LKS yang dikembangkan telah dikembangkan sesuai dengan teori pengembangan perangkat pembelajaran dan pendekatan scientific. Untuk uji kepraktisan RPP yang dilakukan oleh guru dan observer, diperoleh bahwa RPP yang dikembangkan mendapatkan persentase skor kepraktisan $86 \%$ dan dinyatakan praktis. Sedangkan untuk uji kepraktisan LKS dilihat dari hasil analisis lembar angket respon siswa. Berdasarkan hasil analisis yang dilakukan, diperoleh hasil bahwa skor kepraktisan LKS adalah $86,7 \%$ sehingga dinyatakan praktis. Dari data hasil uji keefektifan yang meliputi nilai kuis dan pengerjaan latihan pada LKS menunjukkan bahwa persentase siswa yang mendapatkan nilai lebih dari atau sama dengan 80 yang merupakan SKM adalah $100 \%$. Hal ini menunjukkan bahwa perangkat pembelajaran yang dikembangkan efektif untuk digunakan dalam kegiatan pembelajaran.

i. Berdasarkan uraian di atas, beberapa saran pemanfaatan dan pengembangan yang disampaikan oleh pengembang sebagai berikut:

ii. Hasil pengembangan berupa perangkat pembelajaran berciri scientific ini diharapkan dapat digunakan sebagai alternatif pembelajaran materi barisan aritmatika dan barisan geometri untuk siswa SMP/MTs.

iii. Hasil pengembangan berupa perangkat pembelajaran ini diharapkan dapat digunakan sebagai salah satu contoh atau bahan pertimbangan oleh guru SMP/MTs dalam mengembangkan perangkat pembelajaran berciri scientific.

iv. Pengembangan perangkat pembelajaran yang berciri scientific ini masih terbatas pada materi barisan aritmatika dan barisan geometri untuk siswa SMP kelas IX, untuk itu diharapkan adanya pengembangan perangkat pembelajaran berciri scientific untuk materi lain yang sesuai.

v. Pengembangan perangkat pembelajaran yang berciri scientific ini masih menggunakan Kurikulum Tingkat Satuan Pendidikan (KTSP). Untuk itu, diharapkan adanya pengembangan lebih lanjut untuk penerapan pendekatan scientific pada Kurikulum 2013.

vi. Dalam pengembangan produk yang serupa, aspek kegrafisan pada RPP sebaiknya ditambahkan seperti pemilihan jenis dan ukuran huruf atau hal-hal lain yang sesuai sehingga tidak hanya terpaku pada pengaturan tata letak komponen RPP.

vii. Pengembangan produk dengan materi yang serupa sebaiknya tidak sekedar mengajak siswa mengkonstruksi rumus suku ke-n barisan aritmatika dan barisan geometri, namun juga mengajak siswa menghubungkan konsep-konsep yang 
diperoleh untuk memperoleh pengetahuan yang lebih, seperti mencari contoh barisan aritmatika yang juga merupakan barisan geometri.

viii. Berkaitan dengan kesulitan siswa dalam mengembangkan model, terutama model yang menggambarkan situasi masalah maka pada pengembangan produk serupa perintah atau pertanyaan untuk mendorong siswa sebaiknya lebih jelas sehingga siswa mudah menangkap maksud pertanyaan atau perintah tersebut dan mengurangi kesulitan siswa.

ix. Berkaitan dengan kurangnya kemampuan komunikasi matematika siswa yang tercermin dalam hasil pekerjaan siswa, sebaiknya dilakukan pengembangan produk serupa yang tidak sekedar menerapkan pendekatan scientific, namun juga dapat melatih kemampuan komunikasi matematika siswa.

x. Berkaitan dengan kesulitan siswa dalam menjawab soal-soal yang ada pada LKS yang dikembangkan, sebaiknya dalam pengembangan produk serupa diberikan pertunjuk pengerjaan soal latihan yang lebih detail. Dengan demikian, siswa diharapkan tidak hanya menuliskan langkah-langkah penyelesaian soal melainkan juga cara siswa memahami soal yang diberikan.

xi. Berkaitan dengan instrumen penelitian, sebaiknya dalam menyusun poin-poin dalam instrumen validasi lebih disesuaikan lagi dengan pendekatan yang digunakan dan lebih detail. Dalam satu nomor yang memuat lebih dari satu indikator validasi, sebaiknya indikator-indikator tersebut tidak dijadikan satu melainkan di pisah menjadi beberapa nomor lagi agar tidak menimbulkan kerancuan dalam pemberian skor.

\section{Daftar Rujukan}

Hobri, H. (2010). Metodologi penelitian pengembangan (aplikasi pada penelitian pendidikan matematika). Jember: Pena Salsabila.

Kebudayaan, K. P. D. (2012). Dokumen kurikulum 2013. Jakarta: Kemendikbud.

Kebudayaan, K. P. (2013). Materi pelatihan guru implementasi kurikulum 2013. Nuh, M.(2013). Kurikulum.

Lestari, Ika. (2013). Pengembangan bahan ajar berbasis kompetensi sesuai dengan kurikulum tingkat satuan pendidikan. Jakarta: Indeks.

Nasional, D. P. (2008). Panduan pengembangan bahan ajar. Jakarta: Depdiknas.

Pendidikan, P. M., \& Nomor, K. R. I. (2013). 81A tahun 2013 tentang Implementasi Kurikulum Pedoman Umum Pembelajaran. Jakarta: Kementrian Pendidikan dan Kebudayaan RI.

Prastowo, A. (2012). Panduan kreatif membuat bahan ajar inovatif: Menciptakan metode pembelajaran yang menarik dan menyenangkan [A creative guide to create innovative teaching materials: Creating interesting and fun learning methods].

Setyosari, P. (2001). Rancangan pembelajaran teori dan praktek. Malang: Elang Mas.

Trianto, S. P., \& Pd, M. (2007). Model Pembelajaran Terpadu dalam Teori dan Praktek. Jakarta: Prestasi Pustaka. 